\title{
The Book of Ruth in the time of the Judges and Ruth, the Moabitess
}

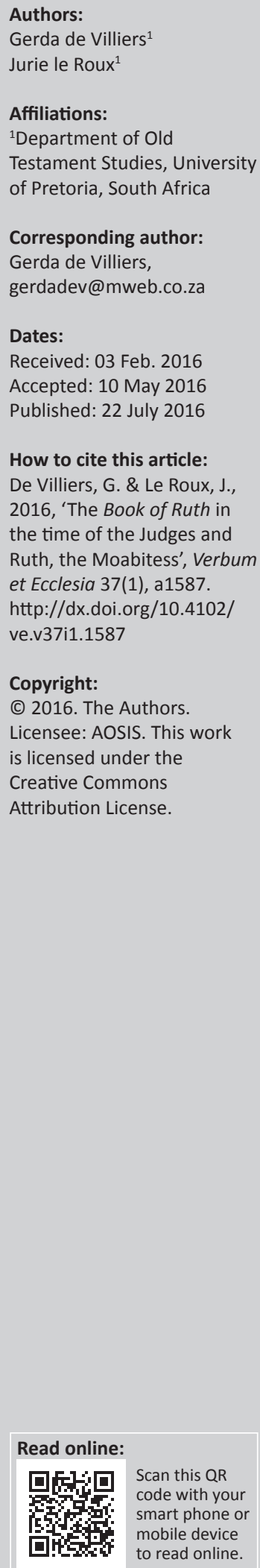

\begin{abstract}
This article addresses two issues in the Book of Ruth that have not yet received much scholarly attention: why is the narrative plotted in the time of the judges, whilst the time of narration dates to the postexilic period, and why is one of the protagonists Ruth, the Moabitess, whilst the law in Deuteronomy 23:3-4 (HB 4-5) clearly forbids the presence of Moabitess and Ammonites in the community of $\mathrm{YHWH}$ ? A suggestion is made that a possible explanation to both these questions may be found in tensions regarding Israel's identity in the Second Temple period. Two different yet not completely opposite viewpoints are illuminated: that of the Books of Ezra and Nehemiah who envisioned an exclusive Israel that is construed along genealogical and religious lines, and that of the Book of Ruth where solidarity with the people of Israel and the worship of YHWH are embraced by foreigners. Both sides are concerned about the identity of Israel and loyalty to $\mathrm{YHWH}$, yet they employ a different jargon in order to argue for the inclusion or exclusion of foreigners. Furthermore, Ezra and Nehemiah consider mixed marriages as a serious threat to Israel's identity, and they justify the expulsion of foreign wives on the basis of the Book of Moses. According to the Book of Deuteronomy, Moses interpreted the Torah for the children of Israel at Mount Nebo in Moab: Moab thus functioned as an interpretive space for the Torah. The Book of Ruth proposes an alternative interpretation of the Torah, also from the plains of Moab and the exegesis comes in the person of Ruth, the Moabitess.

Intradisciplinary and/or interdisciplinary implications: This article challenges the point of view that the Book of Ruth is a charming narrative of loyalty and love. Research reveals that this Book is a polemic document and its main contribution is to the intradisciplinary field of biblical hermeneutics that requests a re-interpretation of texts for changing circumstances.
\end{abstract}

\section{Introduction}

The Book of Ruth opens with the words: 'In the days that the judges judged ...' (Rt 1:1) and one of the protagonists is a Moabite woman, Ruth. Several scholars agree that the Book of Ruth dates to the postexilic period (see Cohn Eskenazi \& Frymer-Kensky 2011:xvi; Fischer 2001:34; Frevel 1992:29; Grätz 2007:277-284; Köhlmoos 2010:XVI; Spangenberg 2000:190; Zakovitch 1999:62; Zenger 1986:27). It has also been pointed out that this book was written as a narrative critique against the community law of Deuteronomy 23:3-4 (HB 4-5) which prohibits the presence of Moabitess and Ammonites in the community of YHWH (see Braulik 1999:1-20; Cook 2015:170; Fischer 2001:34; Korpel 2001:233; LaCocque 2004:1; Matthews 2004:212). This article aims at addressing two questions. Firstly, the narrative is plotted against a specific historical time before the exile, whilst it was written some centuries later. The question is why there is such a vast difference between the 'time of narration' and 'narrated time?' The second question pertains to the choice of 'Ruth, the Moabitess' and not Ruth the Ammonitess, as both Moabitess and Ammonites are forbidden by the law. The article proposes that a possible explanation may be found in the tensions that existed around Israel's identity formation in the period of the Second Temple and the debates on whether the community should include or exclude foreigners in their midst.

\section{Postexilic Israel - a struggle in finding a new identity}

The Babylonian exile was a turning point in the history of Israel. The old Kingdom of Judah had ceased to exist, and together with that, its pre-exilic symbols of national identity, its temple, its city and its king, had vanished (see Albertz 1994:376; Blenkinsopp 2011:462; Cohen 1999:122; Gerstenberger 2005; Lau 2011:176; Le Roux 1987:104;133; Römer 2007:111). However, when the Persians conquered the Babylonians, they allowed the descendants of the exiles to return to their former territory, now called Yehud, a rather small province within the borders of the mighty Persian Empire. However, Davies (1998:65), McNutt (1999:197) and Kessler (2006:105-106) point 
out that this seemingly kind gesture was actually a strategic move by the Persians: the returnees were sent to Yehud to govern and administer the province on behalf of their overlords and especially to collect the necessary taxes. In return they were allowed to rebuild their temple, their city and enjoy religious freedom.

However, for the postexilic community who now referred to themselves as 'Israel' (see Grabbe 2004:168-171 for possible explanations why this term was chosen), matters were rather complicated. In the first place they were not a homogenous group, but there were different groups of 'Israelites' who lived in various regions within the vast Persian Empire. Japhet (2006:69-100), Nihan (2011:67-68), Edelman et al. (2012:68-75) and Knoppers (2015:3) give an overview of this complex demographic situation. Inside the borders of Yehud also lived the descendants of those who did not go into exile. Still within the borders of the province were the returnees from exile, commonly referred to as the 'golah'. Outside the land were colonies in Egypt and in the Eastern Diaspora. Last but not least were foreigners who sometime during the exile attached themselves to Israel and also became faithful worshippers of $\mathrm{YHWH}$.

Of all these groups the 'golah', especially the 'golah-elite' the priests and lay people who were the descendants from the exiles - were the most influential in the postexilic community (Blenkinsopp 2011:472-473; Japhet 2006:97; Kessler 2006:103; Lau 2011:162-163; Römer 2007:167-169; Rom-Shiloni 2011:133-134; Southwood 2011b:205-206). Members of this group had been sent back to Yehud, especially to Jerusalem by the Persian authorities to govern the province on their behalf (Kessler 2006:105-106). Therefore, this group had had a considerable amount of power in their hands, and this power was political as well as religious by nature.

Southwood (2011b:205) further emphasises another matter:

The only legitimate bearers of the name 'Israel' are interpreted as being the returned Gôlāh remnant. Throughout Ezra, selfascription of the titles 'Israel', 'people of Israel' and 'descendants of Israel' appear when describing the reconstituted Gôlāh (Ezr $2: 2,70 ; 3: 1 ; 6: 16,21 ; 7: 7,13 ; 8: 25 ; 9: 1 ; 10: 5)$.

In other words, the term 'Israel' became reserved for one group only within a number of people who all considered them as part of 'Israel'. Noteworthy is the fact that Southwood quotes several passages from the Book of Ezra, and indeed, the Book of Ezra and Book of Nehemiah appear to be representative of the interests of this group which culminate in purging Israel from all foreign elements, for example, the expulsion of foreign women (Ezr 10; Neh 13:23-31; see discussion on mixed marriages below). The assumption can thus be made that this 'golah-elite' envisioned an exclusive Israel to which only the descendants of the exiles belong. Furthermore, it appears that they justified their radical measures of purification on religious grounds.

\section{The jargon of the exclusivists and the inclusivists}

Thus, in establishing the identity of postexilic Israel, it appears that there were different views on who could lay claim to be part of the 'true' Israel. Broadly speaking, two viewpoints emerged: on the one hand, the 'golah-elite' envisioned an exclusive community who consisted of the descendants of the exile only; on the other hand, a more inclusive viewpoint was shaped by an unnamed, unspecific group who foresaw an 'Israel' that also included outcasts and foreigners. However, there was one precondition: the identity of 'Israel' was to be a community who worshipped YHWH; therefore, those who wished to belong to 'Israel' had to worship the God of Israel and to that which is pleasing to him.

Southwood (2011b:205) refers to texts in the Book of Ezra. Especially in this book the ideology of the exclusivists is illuminated, and this concerns the interests of the priestly class in postexilic Israel. Conczorowski and Frevel (2011:63), Southwood (2012:126) and Frevel and Rausche (2014:12) note the priestly terminology that is employed in Ezra 9. This becomes evident in the events leading to Ezra's prayer of penance in Ezra 9:1-2. The leaders of the people come to Ezra and say: 'The people of Israel and the priests and Levites have not separated themselves from the peoples of the lands ... so the holy seed is intermingled ...'. Verse 11 employs the terminology of 'clean and unclean' and 'impurity'. Especially poignant is Ezra's mention of the 'holy seed' (Conczorowski \& Frevel 2011:63; Frevel \& Conczorowski 2011:43; Frevel \& Rausche 2014:12; Knoppers 2001:28; Pakkala 2011:84; Southwood 2011a:54, 2011b:199, 2012:125; Winslow 2011:136). 'Holy seed' is a very powerful metaphor used only by Ezra that somehow merges religious and ethnic concepts to draw impenetrable boundaries around what he considers to be 'Israel', protecting it as it were even before the moment of conception.

The Book of Ezra and Book of Nehemiah both represent the viewpoint of the exclusivists, and in both books, it becomes clear that these exclusivists relied heavily on the 'law' and 'as it is written' in this 'law'. Scharper (2011:30-36) and Grätz (2007:274) notice that for the exclusivist circles references to the 'Torah', 'book of Moses', 'Torah of Moses' or 'Torah of YHWH' were extremely important. Also, if they could state that something 'was written' in any of these 'books' or 'laws', it carried unopposed authority. Terms related to 'Torah' or 'law', and phrases that confirm the written word within these scriptures, were authoritative.

\section{In the time of the judges ...}

Yet, as Scharper (2011:31-33) points out, there are texts, also from the postexilic period that argue for an inclusive community, and he indicates the following: the Book of Jonah, the Book of Judith, the passage from Isaiah 56:1-8 and the Book of Ruth. In these texts references to the 'Torah' and phrases like 'as is written' do not occur at all. Middlemas (2011:119) 
also remarks that Isaiah 56:1-8, when it welcomes foreigners into the YHWH community, uses the term 'berit' (covenant), rather than 'Torah' when it refers to cultic matters. Furthermore, Fischer (2001:91-92) notices that the temple, cult, sanctuary and priestly concerns are conspicuously absent in the Book of Ruth. She adds that the author of the Book of Ruth must have been from the same educated circles as the authors of the Books of Ezra and Nehemiah, and therefore chose deliberately to sidestep the interests of the priests of the time. One can almost say that the authors of the inclusive texts purposeful chose to avoid the characteristic 'jargon' of the exclusive texts - that is, 'book', 'Torah', or 'as it is written' in either the 'book' or the 'law'.

Thus, it is clear that the author of the Book of Ruth is on the side of the inclusivists. In the first place, as Scharper (2011) indicated, he never uses the terms 'Torah', 'book' or the phrase 'as is written'. Also, as Fischer (2001) pointed out, there seems to be a conspicuous absence of all priestly interests that would revolve in and around the temple. One may come to a conclusion that by plotting the Ruth narrative 'in the time of the judges', the author was not simply looking for a peaceful rural setting for his story, but carefully chose a specific historical time: the 'time of the judges'. This is a time before the temple, and before an institutionalised priesthood, a very suitable narrated time for the author of the Book of Ruth to sidestep the jargon of the exclusivist circles.

The 'time of the judges' does not function as a free and lawless time before the Torah. In fact, from phrases like 'the children of Israel die evil in the sight of the LORD' (cf. e.g. Jdg 2:11; 3:7; 12; 6:1 etc.) and from the historical plotting of the Book of Judges just after the exodus, one may deduce that the children of Israel already knew the law. It is important to keep in mind that the author of the Book of Ruth does not want to undermine the authority of the Torah, neither is the implication of the narrative that the characters - Boaz and Ruth - are unaware of what is written in the Torah. The author of this book as well as the characters who play a role in the narrative seem to know 'what is written in the Torah'. However, they never say so, they simply and spontaneously do so.

The 'time of the judges' in the Book of Ruth therefore functions as a literary device, contrary to the jargon that the exclusivists use in order to advocate an inclusive YHWH worshipping community, and to construe the identity of Israel along religious adherence, regardless of genealogy. Firstly, the 'time of the judges' is a suitable time to avoid the priestly terminology and exclusive ideology of the exclusivists, like for example the authors of the Books of Ezra and Nehemiah. Secondly, against the 'time of the judges' where the will of YHWH was neglected and everyone 'did what was right in his own eyes' (cf. e.g. Jdg 17:6; 21:25), the Book of Ruth tells of a foreign Moabite woman whose actions were pleasing to the LORD: she becomes the foremother of Israel's greatest king, King David.

'In the time of the judges', the narrated time, the author of the Book of Ruth looks backward and forward into the history of Israel from the time of narration, the postexilic Second
Temple period. He tells a story of two destitute widows who lived in the time of the judges, Naomi, the Judahite woman and Ruth, her Moabite daughter-in-law, and their selfless solidarity towards each other. The story has a happy ending: Ruth eventually marries Boas, a rich Judahite landlord and some generations later, King David is born from this union. The obvious aim of the story is to encourage the Israelites of the postexilic community to accept foreigners in their midst, foreigners who like Ruth, 'turned her back on her people and her gods' and are now faithful worshippers of $\mathrm{YHWH}$, the God of Israel (Rt 1:16).

However, the story also looks forward. The reality is that the real historic monarchies of both Juda and Israel came to a tragic downfall which for Juda, ended in the Babylonian exile. On the contrary, the acceptance of foreigners like Ruth, may now lead to the inauguration of an eschatological future - the birth of a 'messianic' King David. At this stage it is not clear whether the author of the Book of Ruth may have had political aspirations in mind. One can however assume that he tried to argue for the survival of Israel and Israel's religion within the foreign Empire. The loyalty and solidarity of 'Israelite foreigners' should be welcomed and accommodated at all costs because the contributions of these foreigners are valuable for the community.

One word of caution though: the Book of Ruth does not argue for an unconditional universal inclusivity of foreigners. It should be kept in mind that the Book of Ruth is not diametrically opposite and against the Books of Ezra and Nehemiah. They all have several interests in common: the identity of Israel and the worship of YHWH, the God of Israel. Although the Book of Ruth does not mention 'Torah', it is clear that the author knows perfectly well 'what is written in the Torah' (see e.g. Braulik 1999:1-20). Ezra and Nehemiah wish to construe Israel's identity along genealogical as well as religious lines: for the author of the Book of Ruth - as for the authors of other inclusive texts - religious observance is paramount. Middlemas (2011:117-118) calls this the 'behavioural component'. Nihan $(2011: 81-83,92)$ agrees that the inclusivity suggested by these texts, can in no way be interpreted as an all-inclusive universalism. There are very strict criteria for inclusion into the community: worship YHWH and do what pleases him.

\section{Mixed marriages}

Mixed marriages were a grave concern to the authors of the Books of Ezra and Nehemiah. Ezra, when he arrives in Jerusalem from Persia, he is shocked by the occurrence of mixed marriages among the Judahite people, marriages that are explicitly forbidden by the Torah: Canaanites, Hittites Ferisites, Jebusites, Ammonites, Moabitess, Egyptians and Amorites. Ezra's concern seems to be the prohibition of the nations in Deuteronomy 7:1-7, although he slightly alters the list. Deuteronomy refers to the Hittites, Girgasites, Amorites, Canaanites, Ferisites, Hevites and Jebusites; Ezra omits the Girasites and Hevites but adds the Ammonites, Moabitess and Egyptians. Except for the Egyptians, none of these nations existed as a national state in the period of the second tempel. 
Therefore, scholars consider this list as anachronistic, referring to Israel's archetypical enemies and should be interpreted symbolically, that is, anyone who, in the eyes of Ezra, is considered as non-Israelite (Brenner 2011:85; Fischer 2001:60; Grätz 2011:193; Southwood 2011a:52).

Nehemiah (13:1-2) directly alludes to Deuteronomy 23:3 (HB 4). Although this law does not in the first place pertain to mixed marriages, Nehemiah interpreted it as such and furthermore expanded it to all foreigners (Nihan 2011:77), with the result that not only 'Moabitess and Ammonites' were expelled from the community, but 'all the mixed multitude' were separated. Apparently neither Nehemiah nor Ezra paid heed to those among the nations or the mixed multitude who chose to turn their backs on their people and their gods (Rt 1:16), and eventually sought refuge under the wings of $\mathrm{YHWH}$, the God of Israel (Rt 2:12). In one way or another these foreigners became attached to the people of Israel - certainly by marriage or perhaps merely by sheer conviction - and they sincerely wished to be included by the community who called themselves 'Israel'.

In the Book of Ruth, the birth of King David is realised by a 'mixed marriage', the marriage between Boas, the Judahite man and Ruth, the Moabitess. Also in this regard the Book of Ruth can be read as a protest against Ezra and Nehemiah's campaign against mixed marriages in the Second Temple period. Contamination of the 'holy seed' was one issue - the other was apostasy. Mixing with foreigners, mixed marriages, almost always resulted in apostasy. Conczorowski and Frevel (2011:62) indicate three crucial moments in the history where mixed marriages appear as a threat to Israel: Joshua 23:7-12; Judges 3:6; and 1 Kings 11:1-8. Frevel and Rausche (2014:12) add a fourth instance: Numbers 25 .

The incident that is recorded in Numbers 25 occurs at the border of the promised land. ${ }^{1}$ The Israelites pitch camp at Shittim and there Moabite women seduce Israelite men to commit harlotry, share in the sacrificial meals for their gods and eventually to worship these foreign gods. Joshua 23:7-12 forms part of Joshua's farewell address, just before the occupation of the land. In the land there remain several nations, but Joshua warns the children of Israel not to mix with them, because this will lead to apostasy, turning away from $\mathrm{YHWH}$, worshipping other gods, and eventually they will lose the land.

However soon after entering the land, in the Book of Judges, exactly this starts to happen. From Judges 3 the individual judges are introduced because the children of Israel dwelt among the nations, an exchange between taking and giving daughters followed, with the result that the sons and daughters of Israel started to follow other gods. It is clear that mixed marriages lead to apostasy. The last instance, 1 Kings 11:1-8 is also referred to by Nehemiah (13:26): King Solomon's love for foreign women. This invokes the anger of $\mathrm{YHWH}$ - and soon after the schism of the monarchy follows. The rest of Israel's history steers towards the downfall first of the Northern Kingdom, then of Judah. Thus, mixed marriages means apostasy, means trouble.

\section{Ruth, the Moabitess}

The Book of Ruth also tells about a mixed marriage, but one that does not lead to apostasy, a turn away from YHWH, but one that leads to a 'turn towards' YHWH. One of the main characters in the plot, is Ruth the Moabitess, and in this last part of the article, some reasons are proposed as to why this foreign woman was chosen to play such a key role in the history of Israel - after all, the outcome of this mixed marriage is eventually the birth of King David!

First of all, the Moabitess generally do not get a good report in the Hebrew Bible. The origins of the nation lie in incest: the sexual relationships between Lot and his two daughters in Genesis 19:31-38 (Braulik 1996:117; Cohn Eskenazi \& FrymerKensky 2011:xlvii; Zenger 1986:36). After the destruction of Sodom and Gomorrah, his two daughters are afraid that there will not be any men for them, so they make their father drunk and have sex with him - one daughter the one night, the other daughter the other night. Both become pregnant by their father - the child of the eldest daughter is called Moab: some scholars are of the opinion that Moab is a word play on $m e i$ - $a b h$ (of a father), in other words, the name of the child indicates its origins (Cohn Eskenazi \& Frymer-Kensky 2011:xlvii; Frevel 1992:45). The child of the youngest is BenAmmi, and his descendants are the Ammonites.

Then there is the incident of Numbers 22-24, the story about Balak, king of Moab, who hires Balaam to curse Israel. This is indeed one of the reasons proposed by Deuteronomy 23:4 (HB 5) why Moabitess should be excluded from the community of YHWH. This episode precedes Numbers 25:1, already referred to above: verse 1 specifically name the Moabite women as those who lead the Israelite men into apostasy (Cohn Eskenazi \& Frymer-Kensky 2011:xlvii; Köhlmoos 2010:4; Zenger 1986:36). Cohn Eskenazi and Frymer-Kensky (2011:xlviii) also mention the many wars against the Moabitess attested to in Judges 3:12-30, 1 Samuel 14:47, 2 Samuel 8:2, 2 Kings 3 and 13:20.

However, mention must also be made of single instances where Moab is portrayed in a more positive way. In Deuteronomy 2:9 the Lord forbids the children of Israel to consider the Moabitess as enemies or wage war against them, and according to Deuteronomy 2:27-29 the Moabitess were quite willing to sell water and food to the Israelites - a direct contradiction to Deuteronomy 23:4 and 1 Samuel 22:1-5 tells that David, as he was fleeing from King Saul, requested from the king of Moab to provide shelter to his parents, until the danger passed away (Cohn Eskenazi \& Frymer-Kensky 2011:xlviii; Frevel 1992:45). However, despite the few positive remarks, the evaluation of the Moabitess in the Hebrew Bible is mostly negative. Moabitess, and especially Moabite women in the case of Numbers 25 and King Solomon's love for them, indicate trouble. 


\section{Now why then the Book of Ruth, the Moabite woman?}

Georg Braulik (1996:115-127, 1999:7-19) called the Ruth narrative a 'Gegengeschichte' - a counter story to specifically the law in Deuteronomy 23:3-4, the prohibition of Moabitess in the community of $\mathrm{YHWH}$ and the reasons why they are forbidden: they did not give Israel bread and water during their journey through the desert, instead, they hired Balaam to curse Israel. The whole narrative of Ruth the Moabitess is aimed at correcting this negative image of Moabitess during the postexilic period. Firstly, Moab receives a destitute Judahite family in time of distress by providing them with food and shelter during the famine. However, one might differ here from Braulik: Moab can also be regarded as a negative space, as all the men of this family die in Moab.

Nevertheless, Braulik continues to indicate how the counter story unfolds further as Ruth, the Moabitess provides Naomi, a hungry destitute Judahite woman with bread and water throughout the whole season of the harvest. The scandalous origins of the Moabitess are furthermore corrected by the events between Ruth and Boaz - they are in no way related to each other and their 'marriage' is completely legal.

What Braulik does not explain, is why the author of the Book of Ruth chose Ruth, the Moabite, not Ruth, the Ammonite or even Ruth the Good Samaritan? And why did he specifically choose Moab for the family of Elimelech to flee to? Some scholars are of the opinion that because Moab ceased to exist as an individual political state at the time of the Second Temple - it was completely destroyed already by the Neo Babylonians - it also was no longer considered as a hostile country and a threat (Frevel 1992:47; Köhlmoos 2010:4; Zenger 1986:35). Therefore, Moab seems to be an obvious bordering region where refuge can be found in a time of danger. However, it is not so obvious. Other scholars point out that Moab is on the same sea levels as Judah, therefore would have the same climate as Judah, and famine in Judah would most likely influence Moab as well (Köhlmoos 2010:4).

This article proposes that the author of the Book of Ruth not only chose the historical setting for his narrative deliberately 'in the time of the Judges', but that he also chose the spatial setting for the beginning of this narrative 'on the plains of Moab'. The question then: why Moab, and why a Moabitess? Is Moabitess merely symbolic of any non-Israelite in the time of the Second Temple, just like the Canaanites, Feresites, Hevites and other extinct nations?

It should be remembered that Moses died on Mount Nebo in Moab, just before the children of Israel entered the land (Cohn Eskenazi \& Frymer-Kensky 2011:5; Köhlmoos 2010:4; LaCocque 2004:36). His long speech in more or less the whole of the Book of Deuteronomy, was an interpretation of the Torah. This Torah is still in the hands of the leaders of the postexilic community who seek guidance in this authoritative document and finds in it the basis for determining Israel's identity. Ezra and Nehemiah call it the Book of Moses and they execute their understanding of this Torah often with violent and harsh measures.

With regard to the Book of Ruth, LaCocque (2004:1) states: 'From beginning to end, this delicious story is based on an interpretation of the Torah.' Fischer (2006:3) also describes the Book of Ruth as 'exegetische literatur' and argues that the book '... arbeitet nicht nur mit erhälenden Texten der Tora, sondern ebenso mit Rechtstexten'. The Book of Ruth is well acquainted with the narrative texts as well as the legislation in the Torah but offers an interpretation that differs from the one proposed by the exclusivists. This interpretation also comes from the plains of Moab and is done by means of 'narrative exegesis'.

The story is told of a Moabitess, a foreigner who is forbidden by the law, but who demonstrates her solidarity with her mother-in-law's people and proposes to worship her God (Rt 1). The presence of this foreign woman on Judahite soil creates no tension at all, in fact, she receives the most generous treatment by the landowner himself (Rt 2). This encounter eventually leads to marriage (Rt 3-4), a mixed marriage, one of the greatest transgressions in the history and legislation of Israel. However, the outcome of this marriage is not apostasy, but the birth of a national king (Ruth 4). Instead of the downfall of the monarchy as was the result of King Solomon's mixed marriages, the marriage between Boaz and Ruth looks forward to a promising future.

\section{Conclusion}

The aim of this article was to examine two narrative devices in the Book of Ruth that have not yet received specific attention, namely: why is the narrative plotted against the background of the 'time of the judges' whilst the book clearly dates to the postexilic period, and why is one of the protagonists Ruth, the Moabitess, whilst the law in Deuteronomy 23:3-4 (HB 4-5) forbids the presence of both Moabitess and Ammonites in the community of YHWH? The article then expounded on the tensions around Israel's identity formation in the Second Temple period and the different viewpoints that existed between the exclusivists as represented by the authors of the Books of Ezra and Nehemiah, and the inclusivists, those scribes who were responsible of texts like the Book of Jonah, the Book of Judith, the Book of Ruth and a text like Isaiah 56:1-8. Although both parties were concerned about Israel's identity and religious observations, they expressed their different viewpoints by means of the jargon they used: either by directly referring to 'as is written in the Torah', or by sidestepping these terms completely, and indirectly, yet equally compelling, allude to that which would be pleasing to $\mathrm{YHWH}$.

The second point is that this alternative interpretation is offered from the 'plains of Moab'. Instead of the Book of Moses and the understanding of Ezra and Nehemiah of this 'Book', the Book of Ruth is written to propose an inclusive community and an execution of the Torah in terms of YHWH who is far greater than his Torah. 


\section{Acknowledgements Competing interests}

The authors declare that they have no financial or personal relationships which may have inappropriately influenced them in writing this article.

\section{Authors' contributions}

This article is based on a PhD dissertation with the title: Israel se Identiteit en die Boek Rut. The degree was awarded on 14 February 2016. J.1.R. was the promotor and G.d.V. was the candidate.

\section{References}

Albertz, R., 1994, A history of Israelite Religion in the Old Testament period. Volume II: From the exile to the Maccabees, transl. J. Bowden, SCM Press, London.

Blenkinsopp, J., 2011, 'Judaens, Jews, Children of Abraham', in O. Lipschits, G.N. Knoppers \& M. Oeming (eds.), Judah and the Judeans in the Achaemenid period. Negotiating identity in and international context, pp. 461-482, Eisenbrauns, Winona Lake, IN

Braulik, G., 1996, 'Das Deuteronomium und die Bücher ljob, Sprichwörter, Rut', in E. Zenger (Hg.), Die Tora als Kanon für Juden und Christen, pp. 61-138, Herder, Freiburg.

Braulik, G., 1999, 'The Book of Ruth as Intra-Biblical Critique on the deuteronomic Law', Acta Theologica 1, 1-20.

Brenner, A., 2011, 'Ruth: The art of memorizing territory and religion', in D.J.A. Clines \& E. Van Wolde (ed.), A critical engagement. Essays on the Hebrew Bible in Honour of J. Cheryl Exum, pp. 82-89, Sheffield Academic Press, Sheffield.

Cohen, S.J.D., 1999, The beginnings of Jewishness: Boundaries, varieties, uncertainties Hellenistic Culture and Society, University of California Press, Berkeley, CA.

Cohn Eskenazi, T. \& Frymer-Kensky, T., 2011, Ruth, The Jewish Publication Society, Philadelphia, PA.

Conczorowski, B. \& Frevel, C., 2011, 'Mischen und die Suche nach Identität in der Proviz Jehud. Ungeliebte Scwiechertöchter', Welt und umwelt der bibel 3, 60-63.

Cook, L.S., 2015, Reading Deuteronomy. A literary and theological commentary, Smyt \& Helwys Publishing, Inc, Macon, GA.

Davies, P.R., 1998, Scribes and schools. The canonization of the Hebrew Scriptures, Westminster John Knox Press, Louisville, KY.

Edelman, D.V., Davies, P.R., Nihan, C. \& Römer, T. (eds.), 2012, Opening the books of Moses, Equinox Pub, Sheffield.

Fischer, I., 2001, Rut, Herder, Freiburg im Bresgau.

Fischer, I., 2006, 'Das Buch Rut Als Exegetische Literatur', Bibel Forum, 1-7, viewed 30 September 2014, http://www.haus-ohrbeck.de/download/VortraglrmtraudFischerdeutsch.pdf

Frevel, C., 1992, Das Buch Rut, Verlag Katholisches Bibelwerk GmbH, Stuttgart.

Frevel, C. \& Conczorowski, B.J., 2011, 'Deepening the water: First steps to a diachronic approach on intermarriage in the Hebrew Bible', in C. Frevel (ed.), Mixed marriages, intermarriage and group identity in the Second Temple period, $\mathrm{pp}$ 15-45, T\&T Clark International, London.

Frevel, C. \& Rausche, B., 2014. 'Mixed marriages as a challenge to identity in Second Temple Judaism', pp. 1-12, viewed 04 July 2015, from http://www.bibleinterp. com/articles/fre318503.shtml

Gerstenberger, E.S., 2005, Israel in der Perserzeit 5. Und 4. Jahrhundert v Chr. Stuttgart, Kohlhammer.

Grabbe, L.L., 2004, A history of the Jews and Judaism in the Second Temple period, Volume 1. Yehud: A history of the Persian Province of Judah, T\&T Clark International, London.

Grätz, S., 2007, 'Second Temple and the Legal Status of the Torah: The Hermeneutics of the Torah in the Books of Ruth and Ezra', in G.N. Knoppers \& B.M. Levinson (eds.) The Pentateuch as Torah. New models for understanding its promulgation and acceptance, pp. 273-287, Eisenbrauns, Winona Lake, IN.
Grätz, S., 2011 'The Question of "Mixed Marriages" (Intermarriage): The ExtraBiblical Evidence', in C. Frevel (ed.), Mixed Marriages, Intermarriage and Group Identity in the Second Temple Period, pp. 192-204, London, T\&T Clark.

Japhet, S., 2006, From the rivers of Babylon to the Highlands of Judah. Collected Studies on the restoration period, Eisenbrauns, Winona Lake, IN.

Kessler, J., 2006, 'Persia's Loyal Yahwists: Power identity and ethnicity in Achaemenid Yehud', in O. Lipschits \& M. Oeming (eds.), pp. 91-121, Judah and the Judeans in the Persian period, Eisenbrauns, Winona Lake, IN.

Knoppers, G.N., 2001, 'Intermarriage, social complexity, and ethnic diversity in the genealogy of Judah', Society of Biblical Literature 120(1), 15-30, viewed 04 July 2015, from http://www.jstor.org/stable/3268591

Knoppers, G.N., 2015, 'The construction of Judean Diasporic identity in EzraNehemiah', Journal of Hebrew Scriptures 15(3), 1-29. http://dx.doi.org/10.5508/ jhs.2015.v15a3

Köhlmoos, M., 2010, Ruth, Vandenhoeck \& Ruprecht, Göttingen

Korpel, M.C.A., 2001, The structure of the Book of Ruth, Koninklijke Van Gorcum, Assen.

LaCocque, A., 2004, Ruth, transl. from French by K.C. Hanson, Fortress Press, Minneapolis, MN.

Lau, P.H.W., 2011, Identity and ethics in the Book of Ruth. A social identity approach, De Gruyter, Berlin.

Le Roux, J.H., 1987, 'Teologie in "n krisis"', in F.E. Deist \& J.H. Le Roux (eds.), Rewolusie en Reïnterpretasie. Die Literatuur van die Ou Testament, pp. 101-159, Deel 4, Tafelberg, Kaapstad.

Matthews, V., 2004, Judges and Ruth, Cambridge University Press, Cambridge.

McNutt, P., 1999, Reconstructing the Society of Ancient Israel, John Knox Press, Westminster, CO.

Middlemas, J., 2011, 'Trito-Isaiah's Intra and internationalization. Identity markers in the Second Temple period', in O. Lipschits, G.N. Knoppers \& M. Oeming (eds.) Judah and the Judeans in the Achaemenid period. Negotiating identity in an international context, Eisenbrauns, Winona Lake, IN.

Nihan, C., 2011, 'Ethnicity and identity in Isaiah 56-66', in O. Lipschits, G.N. Knoppers \& M. Oeming (eds.), Judah and the Judeans in the Achaemenid period. Negotiating identity in an international context, pp. 67-104, Eisenbrauns, Winona Lake.

Pakkala, J., 2011, 'Intermarriage and Group Identity in the Ezra Tradition (Ezra 7-10 and Nehmiah 8)', in C. Frevel (ed.), Mixed Marriages, Intermarriage and Group Identity in the Second Temple Period, pp. 78-88, London, T\&T Clark International.

Römer, T., 2007, The so-called deuteronomistic history, T\&T Clark, London.

Rom-Shiloni, D., 2011, 'From Ezikiel to Ezra-Nehemiah: Shifts of group identities within the Babylonian exile ideology', in O. Lipschitz, G.N. Knoppers \& M. Oeming (eds.), Judah and the Judeans in the Achaemenid period, pp. 127-151, Eisenbrauns, Winona Lake, IN.

Scharper, J., 2011, 'Torah and identity in the Persian period', in O. Lipschits, G.N. Knoppers \& M. Oeming (eds.), Judah and the Judeans in the Achaemenid period. Negotiating identity in an international context, pp. 27-38, Eisenbrauns, Winona Lake, IN.

Southwood, K.E., 2011a, 'An ethnic affair? Ezra's intermarriage Crisis against a context of "self Ascription" and "Ascription of Others"', in C. Frevel (ed.), Mixed marriages, intermarriage and group identity in the Second Temple period, pp. 46-59, T\&T Clark International, London.

Southwood, K.E., 2011b, 'The Holy Seed: The significance of endogamous boundaries and their transgression in Ezra 9-10', in O. Lipschits, G.N. Knoppers \& M. Oeming (eds.), Judah and the Judeans in the Achaemenid period. Negotiating identity in an international context, pp. 189-224, Eisenbrauns, Winona Lake, IN.

Southwood, K.E., 2012, Ethnicity and the mixed marriage Crisis in Ezra 9-10. An anthropological approach, Oxford University Press, Oxford.

Spangenberg, I., 2000, 'The literature of the Persian period (539-333 BCE)', in W. Boshoff, E. Scheffler \& I. Spangenberg (eds.), Ancient Israelite literature in context, pp. 168-198, Protea Boekhuis, Pretoria.

Winslow, K.S., 2011, 'Mixed marriages in Torah narratives', in C. Frevel (ed.), Mixed marriages, intermarriage and group identity in the Second Temple period, pp. 132-149, T\&T Clark, London.

Zakovitch, Y., 1999, Das Buch Rut. Ein jüdischer Kommentar, Verlag Katholisches Biblewerk GmbH, Stuttgart.

Zenger, E., 1986, Das Buch Ruth, Theologischer Verlag, Zürich. 